\title{
Analisis Proses Perencanaan dan Penganggaran APBD (Studi Kasus pada Pemerintah Kabupaten Bolaang Mongondow)
}

\author{
AMNA PAPUTUNGAN ${ }^{1}$, VENTJE ILAT ${ }^{2}$, JENNY MORASA ${ }^{3}$ \\ ${ }^{1,2,3}$ Program Magister Akuntansi, Fakultas Ekonomi dan Bisnis Universitas Sam Ratulangi \\ email : amnapaputungan12@gmail.com
}

\begin{abstract}
Local Government Financial Management is a subsystem of State Government Financia Management. It is also a substantial element in operating local governance effectively, efficiently and economically by fulfilling main pillars of government operation. Those main pillars are transparency, accountability, and participative. These pillars are determined by the Indonesian Government Regulation Number 58 year 2005 and Permendagri Number 13 year 2006. The stages include planning and budgeting process, starting from absorption of people's aspiration, setting up and the implementation of detailed planning and budgeting as regulated by constitutions. There are obstacles in the planning and budgeting process in Local Government of Bolaang Mongondow. Those obstacles are in Musrenbang stage, Local Government Budgeting Team, process of setting up KUA-PPAS and RKA-SKPD, budget discussion between DPRD members and APBD budgeting staff. This research also discusses their efforts to overcome the obstacles in the process of planning and budgeting of Local Government of BolaangMongondow APBD. This is a qualitative case study research. Data were collected by interviews and observation. Respondents are staff involving in the process of planning and budgeting. They are Government employees and members of DPRD in the Local Government of Bolaang Mongondow. This study undertook more than 2 months for collecting its data. Results indicate that the process planning and budgeting of APBD in the Local Government of Bolaang Mongondow has not fulfilled yet the regulations. Results also show that transparency is not yet conducted sufficiently and people's aspirations have not been absorbed optimally, either bottom up or top down approach. It is, thus, efforts are needed to overcome such obstacles in the process of planning and budgeting of APBD in the Local Government of BolaangMongondow.
\end{abstract}

Keywords: Local government planning and budgeting, people's aspiration, Permendagri Number 58 year 2005, Permendagri Number 13 year 2006

Abstrak. Pengelolaan Keuangan Daerah merupakan sub system dari Pengelolaan Keuangan Negara serta merupakan elemen pokok dalam penyelenggaraan Pemerintahan Daerah dalam rangka pengelolaan Keuangan Negara dan Daerah yang efektif, efisien dan ekonomis melalui tata kelola pemerintahan yang memenuhi pilar utama yaitu transparansi, akuntabilitas, dan partisipatif. Yang telah diatur dalam Peraturan Pemerintah Nomor 58 Tahun 2005 dan Permendagri Nomor 13 Tahun 2006. Dimana tahapan proses perencanaan dan penganggaran dimulai dari penyerapan aspirasi masyarakat, waktu penyusunan, sampai pada tata cara pelaksanaan perencanaan dan penganggaran sudah diatur sedetail mungkin dalam peraturan perundang-undangan.Proses perencanaan dan penganggaran di Pemerintah Kabupaten Bolaang Mongondow terdapat kendala-kendala dalam hal ini dimulai dari tahapan Musrenbang, peran Tim Anggaran Pemerintah Daerah, proses penyusunan KUA-PPAS, proses penyusunan RKA-SKPD, pembahasan anggaran dengan pihak DPRD dan penetapan anggaran APBD. Sehingga dalam penelitian ini ada upaya untuk mengatasi kendala yang terjadi dalam proses perencanaan dan penganggaran APBD di Pemerintah Kabupaten Bolaang Mongondow. Penelitian ini menggunakan pendekatan kualitatif metode studi kasus, pengumpulan data dilakukan melalui observasi dan wawancara dengan orang-orang yang terkait dalam proses perencanaan dan penganggaran yang berasal dari Aparatur Sipil Negara dan anggota DPRD Pemerintah Kabupaten Bolaang Mongondow. Penelitian ini difokuskan pada Proses Perencanaan dan Penganggaran di Pemerintah Kabupaten Bolaang Mongondow, dengan waktu penelitian kurang lebih 2 bulan. Hasil penelitian menunjukkan bahwa perencanaan dan penganggaran APBD di Pemerintah Kabupaten 
Bolaang Mongondow belum mematuhi peraturan perundang-undangan yang ada serta belum memaksimalkan transparansi dan keterlibatan masyarakat dalam hal ini pendekatan Bottom Up dan Top Down belum berjalan secara optimal. Sehingga harus ada upaya dalam menghadapi kendala dalam proses perencanaan dan penganggaran APBD di Pemerintah Kabupaten Bolaang Mongondow.

Kata Kunci: Perencanaan dan Penganggaran Daerah, Partisipasi Masyarakat, Permendagri Nomor 58 Tahun 2005 Permendagri Nomor13 Tahun 2006

\section{PENDAHULUAN}

Negara yang besar dengan sumber daya alam yang melimpah Indonesia memiliki potensi yang besar untuk menjadi salah satu bangsa yang maju dan lebih baik dari saat ini, dan itu semua dapat terwujud tentunya dengan dukungan sumber daya manusia yang berkualitas dan tata kelola pemerintahan yang baik, kreatif dan memiliki visi-misi yang jelas dan terarah untuk kemajuan bangsa. Karena maju mundurnya suatu pemerintahan, salah satunya sangat ditentukan oleh kesungguhan dan kemampuan dalam mengelola tata pemerintahan yang baik serta didukung oleh sumber daya manusia yang memadai. Jika tidak demikian, maka tata pemerintahan tidak akan berjalan dengan optimal.

Seiring dengan keinginan dan kebutuhan publik di tingkat daerah yang menuntut pemerintah pusat untuk memperhatikan tingkat pelayanan kepada publik sampai pada tingkat daerah, sehingga pemerintah pusat dalam mewujudkan keinginan dan kebutuhan publik di tingkat daerah, tonggak sejarah reformasi perencanaan keuangan daerah ditandai dengan pelaksanaan desentralisasi dan otonomi daerah yang dimulai 1 Januari 2001, desentralisasi yaitu penyerahan kewenangan dari pemerintah pusat kepada pemerintah daerah untuk mengurus urusan rumah tangganya sendiri berdasarkan prakarsa dan aspirasi dari rakyatnya dalam kerangka Negara Kesatuan Republik Indonesia. Dengan adanya desentralisasi maka pemerintah daerah dapat menyusun, mengatur dan mengurus sendiri daerahnya sendiri tanpa ada campur tangan pemerintah pusat.

Tujuan pelaksanaan otonomi daerah tersebut secara umum yaitu untuk meningkatkan kemandirian daerah, memperbaiki transparansi, dan akuntabilitas publik atas pengelolaan keuangan daerah juga meningkatkan efisiensi dan efektifitas pengelolaan keuangan dan pelayanan kepada publik serta mendorong demokrasi di daerah. Mardiasmo (2004:59) tujuan utama penyelenggaraan otonomi daerah adalah untuk meningkatkan pelayanan publik (public service) dan memajukan perekonomian daerah. Agar pemerintah daerah dapat meningkatkan pelayanan pada publik dengan maksimal, maka salah satu cara yang dapat dipertimbangkan untuk dilaksanakan yaitu mengimplementasikan kebijakan di bidang perencanaan keuangan yang taat prosedur. Hal ini dilatari oleh suatu pandangan bahwa dalam rangka mencapai tujuan perencanaan keuangan yang efektif dan efisien, tahapan dalam usaha pencapaian tujuan maka harus dilakukan secara berjenjang, mulai dari tahap awal hingga tahap akhir. Diyakini organisasi pemerintahan dapat mencapai tujuan yang efektif dan efisien.

Upaya perbaikan pengelolaan keuangan daerah, khususnya penganggaran di Pemerintah Kabupaten Bolaang Mongondow, masih merupakan agenda strategis bagi percepatan peningkatan kesejahteraan rakyat di daerah, yang merupakan inti dari Kewajiban Daerah, DPRD, dan Kepala Daerah. Bila diarahkan ke lokus penelitian ini yaitu di Pemerintah Kabupaten Bolaang Mongondow, maka ke empat faktor dominan dalam penganggaran diatas patut mendapat perhatian. Dikatakan demikian, karena untuk mencapai visi dan misi Kabupaten Bolaang Mongondow, dalam rangka "mewujudkan masyarakat Bolaang Mongondow yang berbudaya, berdaya saing, dan sejahtera" dibutuhkan kemampuan manajemen yang handal, maka faktor dominan dalam penganggaran akan memberikan manfaat yang positif bagi Pemerintah Kabupaten Bolaang Mongondow, guna memberikan pelayanan terbaik kepada masyarakat.

Mahsun et. al transparansi adalah memberikan informasi keuangan yang terbuka dan jujur kepada masyarakat berdasarkan pertimbangan bahwa masyarakat memiliki hak untuk mengetahui secara terbuka dan menyeluruh atas pertanggungjawaban pemerintah dalam mengelola sumberdaya yang ada dan ketaatan pada peraturan perundang-undangan. Namun, proses tersebut umumnya 
hanya sekedar menjadi ritual formal, belum lagi hasil dari reses anggota DPRD dan audiens Bupati dapat mengesampingkan hasil dari musrenbang. Akibatnya, perencanaan kegiatan yang seharusnya telah menjadi kesepakatan pada bulan Mei justru tidak mendapatkan perhatian serius. Akhirnya rencana kegiatan dibahas lagi pada tahap penganggaran dan menjadi obyek transaksi yang mengalami tarik ulur dan kadang kala berlarut-larut sehingga menyebabkan molornya penetapan APBD.

Bastian (2010:71) hasil yang ingin dicapai dalam perencanaan sektor publik adalah kesejahteraan publik, dimana dalam proses penganggaran pemerintahan Kabupaten Bolaang Mongondow ditujukan dalam rangka meningkatkan kesejahteraan masyarakat. Berangkat dari proses penganggaran yang sesuai dengan kebutuhan dan komitmen berbagai pihak terkait, maka kesejahteraan masyarakat di Kabupaten Bolaang Mongondow akan tercapai.

Kesejahteraan masyarakat sebagaimana tersebut diatas, perlu dikedepankan karena tuntutan reformasi khususnya di bidang anggaran. Hal ini seiring dengan pendapat Mardiasmo (2009:62) anggaran sektor publik dibuat untuk membantu menentukan tingkat kebutuhan masyarakat. Jadi, tahapan proses penyusunan anggaran yang dilaksanakan merupakan cerminan bagi terlaksananya reformasi bidang anggaran yang efisien dan efektif. Disamping itu, Bastian (2010:95) berbagai sistem penganggaran organisasi sektor publik dikembangkan untuk mencapai berbagai tujuan, termasuk pengendalian keuangan, rencana manajemen, prioritas penggunaan dana, dan pertanggungjawaban kepada publik.

Namun dalam tahapan perencanaan dan penganggaran APBD di Pemerintah Kabupaten Bolaang Mongondow masih jauh dari apa yang diamanatkan dalam peraturan dan perundangundangan yang ada. Ada fenomena menarik terkait proses perencanaan dan penganggaran tersebut, sebenarnya fenomena ini bukan masalah baru. Tetapi masalah yang dari tahun ke tahun seringkali berulang. Karena sebagai suatu masalah yang berpotensi merugikan masyarakat, maka seharusnya menjadi perhatian bersama terutama bagi pemerintah daerah. Secara mekanisme, tahapan perencanaan dan penganggaran di Pemerintah Kabupaten Bolaang Mongondow meliputi proses yang panjang mulai dari musyawarah pembangunan di tingkat desa dari bulan Januari, penetapan Rencana Kerja Tahunan pada bulan Mei, penyusunan usulan anggaran bulan Agustus, sampai dengan penetapan APBD sendiri pada bulan Desember.

Proses yang panjang tersebut dapat dibagi menjadi dua, yaitu tahap perencanaan dan tahap penganggaran. Tahapan perencanaan, tujuannya adalah menghasilkan dokumen Rencana Kerja Pemerintah Daerah (RKPD) yang berisi daftar kegiatan yang secara logis dilakukan oleh pemerintah pada tahun depan, sedangkan jumlah pendanaan yang dibutuhkan oleh kegiatan-kegiatan tersebut baru akan diputuskan pada tahap penganggaran yang dimulai pada bulan Juli dan berakhir dengan penetapan APBD di bulan Desember. Dari tahapan-tahapan tersebut, dapat diidentifikasi beberapa faktor yang menjadi penyebab molornya penetapan APBD.

Kegagalan sistem perencanaan dalam proses musyawarah pembangunan, baik ditingkat desa, kecamatan maupun kabupaten/kota seharusnya diikuti oleh berbagai unsur masyarakat pada proses yang berujung pada dokumen Rencana Kerja Pemerintah tersebut sebagian besar aspirasi masyarakat termasuk pokok-pokok pikiran DPRD seharusnya telah tersalur. Dengan demikian, daftar kegiatan dalam rencana kerja merupakan kesepakatan seluruh pemangku kepentingan yang seharusnya "tidak perlu diperdebatkan lagi" dalam hal ini Pemerintah Kabupaten Bolaang Mongondow belum transparan kepada masyarakat dalam proses perencanaan dan penganggaran.

Mahsun et. al transparasi adalah memberikan informasi keuangan yang terbuka dan jujur kepada masyarakat berdasarkan pertimbangan bahwa masyarakat memiliki hak untuk mengetahui secara terbuka dan menyeluruh atas pertanggungjawaban pemerintah dalam mengelola sumber daya yang ada dan ketaatan pada peraturan perundang-undangan. Namun, proses tersebut umumnya hanya sekedar menjadi ritual formal, belum lagi hasil dari reses anggota DPRD dan audiens Bupati dapat mengesampingkan hasil dari Musrenbang. Akibatnya, perencanaan kegiatan yang seharusnya telah menjadi kesepakatan pada bulan Mei justru tidak mendapatkan perhatian serius. Akhirnya rencana kegiatan dibahas lagi pada tahap penganggaran dan menjadi obyek transaksi yang mengalami tarik ulur dan kadang kala berlarut-larut sehingga menyebabkan molornya penetapan APBD. 
Kegagalan pemerintah dalam meletakkan kerangka proses perencanaan dan penganggaran yang terpadu dan efisien. Akibatnya, Pemerintah Daerah dalam proses penyusunan APBD lebih banyak membuang waktu pada hal-hal yang sebenarnya tidak terlalu penting. Hal-hal tersebut diperparah oleh kapasitas SDM di Pemerintah Daerah yang umumnya mengalami kesulitan dalam menerjemahkan substansi yang dikehendaki pemerintah pada level teknis.

Dari berbagai persoalan yang timbul sehubungan dengan pengelolaan keuangan daerah dimana dipandang perlu untuk mengidentifikasi permasalahan-permasalahan atau faktor-faktor apa yang menjadi penyebabnya sehingga penulis tertarik untuk Menganalisis Proses Perencanaan dan Penganggaran APBD pada Pemerintah Kabupaten Bolaang Mongondow. Diharapkan dengan hasil dari identifikasi tersebut dapat dijadikan solusi yang tepat sehingga dengan demikian pelaksanaan anggaran dapat memenuhi azas pengelolaan keuangan daerah itu sendiri yaitu partisipatif, transparan dan akuntabel.

1. Rumusan Masalah

Adapun rumusan masalah dalam penelitian ini adalah sebagai berikut :

1. Bagaimana proses perencanaan dan penganggaran APBD di Pemerintah Kabupaten Bolaang Mongondow?

2. Apakah kendala-kendala dalam proses perencanaan dan penganggaran APBD di Pemerintah Kabupaten Bolaang Mongondow?

3. Apakah upaya-upaya yang dilaksanakan Pemerintah Kabupaten Bolaang Mongondow untuk mengatasi kendala-kendala yang ada?

\section{Tujuan Penelitian}

Berdasarkan pendahuluan dan rumusan masalah, maka peneliti bertujuan untuk menganalisis proses perencanaan dan penganggaran di Pemerintah Kabupaten Bolaang Mongondow dan relevansinya dengan regulasi mengenai pengelolaan keuangan daerah, serta apa saja kendalakendala dalam proses penyusunan anggaran bahkan ingin mengungkapkan apa saja permasalahan yang ditemui oleh pemerintah daerah dalam pengelolaan APBD.

\section{MODEL ANALISIS}

Model analisis penelitian ini dikonsep melalui observasi dan wawancara dengan orang-orang yang terkait dalam proses perencanaan dan penganggaran yang berasal dari Aparatur Sipil Negara dan anggota DPRD Pemerintah Kabupaten Bolaang Mongondow.

\section{METODE PENELITIAN}

Metode yang digunakan dalam penelitian ini adalah pendekatan kualitatif metode studi kasus. Studi kasus merupakan salah satu jenis penelitian kualitatif, dimana peneliti melakukan ekplorasi secara mendalam terhadap program, kejadian, proses, aktivitas terhadap satu orang atau lebih, (Sugiyono $2015: 17$ ).

Teknik pengumpulan data yang digunakan adalah melalui pengamatan/observasi (observation), wawancara mendalam (indepth interview), dokumentasi (documentation) dan triangulasi (triangulation), sesuai standar yang ditetapkan (Sugiyono, 2015). Selanjutnya, uji keabsahan data meliputi uji credibility (validitas internal), transferability (validitas eksternal), dependability (reliabilitas) dan confirmability (objektivitas).

Menurut Bungin (2015: 264) salah satu cara paling penting dan mudah dalam uji keabsahan data atau uji validitas hasil penelitian kualitatif adalah dengan melakukan triangulasi peneliti, metode, teori dan sumber data. 


\section{ANALISIS DAN PEMBAHASAN}

Proses analisis data yang digunakan dalam penelitian ini merupakan teknik yang merujuk pada Bungin (2015:242), Triangulasi diartikan sebagai teknik pengumpulan data yang bersifat menggabungkan dari berbagai teknik pengumpulan data dan sumber data yang telah ada.

Pelaksanaan penelitian dilakukan selama kurang lebih 2 (dua) bulan, sejak Desember 2016 hingga Februari 2017. Dalam melaksanakan penelitian peneliti menggunakan instrumen pendukung (alat perekam: audio/video recorder, kamera, buku catatan dan alat tulis). Instrumen ini digunakan untuk menunjang hasil penelitian agar dapat memperoleh dan menggali informasi sebanyakbanyaknya tentang permasalahan yang ada, sehingga bisa diketahui kendala-kendala apa yang ada dalam proses perencanaan dan penganggaran APBD di Pemerintah Kabupaten Bolaang Mongondow dan upaya-upaya apa yang dapat dilakukan guna perbaikan di masa yang akan datang.

Data wawancara, data dokumen, dan data observasi langsung diperoleh peneliti, diketik dalam bentuk transkrip hasil wawancara dengan informan-informan kunci, kemudian menjadi transkrip wawancara, kemudian dilakukan organisasi data yaitu kategorisasi dan coding berdasarkan rumusan masalah dan pertanyaan peneliti. Hasil coding dilakukan pemahaman peneliti untuk menemukan tema yang ada guna menjawab permasalahan yang diajukan oleh peneliti, dalam rumusan masalah yaitu sebagai berikut :

1. Bagaimana proses perencanaan dan penganggaran APBD di Pemerintah Kabupaten Bolaang Mongondow?

2. Apakah Kendala-kendala dalam proses perencanaan dan penganggaran APBD di Pemerintah Kabupaten Bolaang Mongondow?

3. Apakah upaya-upaya yang dilaksanakan Pemerintah Kabupaten Bolaang Mongondow untuk mengatasi kendala-kendala yang ada?

Peneliti menemukan kategorisasi/coding, 6 (enam) tema penting yaitu: pertama, pelaksanaan Musrenbang; kedua, peran TAPD; ketiga, penyusunan KUA-PPAS; keempat, penyusunan RKA-SKPD, Kelima, pengalokasian anggaran; keenam, upaya-upaya yang dilakukan.

1. Pelaksanaan Musrenbang.

Berdasarkan hasil penelitian diperoleh informasi, Pemerintah Kabupaten Bolaang Mongondow dalam penyusunan anggaran telah mengacu pada Permendagri Nomor 21 Tahun 2011 yaitu Perubahan kedua atas Permendagri Nomor 13 Tahun 2006 Tentang Pengelolaan Keuangan Daerah dan Permendagri Nomor 59 Tahun 2007, khusus di Pemerintah Kabupaten Bolaang Mongondow mekanismenya adalah sebagaimana dalam Permendagri Nomor 21 Tahun 2011 yaitu perubahan kedua Permendagri Nomor 13 Tahun 2006, melalui tahapan proses, tahapan itu mulai dari awal tahun dimulai dari Musrenbang tingkat desa, Musrenbang tingkat kecamatan, Musrenbang tingkat kabupaten dan Musrenbang tingkat provinsi serta Musrenbang tingkat nasional. Lewat Musrenbang itu didapatilah usulan-usulan masyarakat sesuai kebutuhan di masyarakat yang disinkronkan dengan visi-misi dan RPJMD dari Bupati dan Wakil Bupati. Akan tetapi proses penyusunan anggaran daerah yang mekanismenya dimulai dari tingkat desa, kecamatan hingga kabupaten ada kendala-kendala dalam proses perencanaan APBD ditahapan Musrenbang yaitu sebagai berikut :

a. Tidak efektifnya Musrenbang karena tidak mengikuti Peraturan perundang-undangan yang ada.

b. Tidak Sinkronnya antara hasil Musrenbang dan hasil reses anggota DPRD serta hasil audiens Bupati.

2. Peran Tim Anggaran Pemerintah Daerah.

Kendala yang dihadapi Tim Anggaran Pemerintah Daerah untuk memaksimalkan perannya dalam proses perencanaan semuanya tidak lepas dari berbagai faktor yang menghambat penerapannya, dari hasil penelitian ditemukan beberapa faktor penghambat peran TAPD di Pemerintah Kabupaten Bolaang Mongondow Yaitu :

a. Penentuan jadwal pembahasan kurang baik, karena adanya kesibukan pihak eksekutif dan legislatif. 
b. Kurangnya komunikasi dan koordinasi antara TAPD dan Pihak legislatif DPRD sehingga berdampak pada tahapan pembahasan yang terburu-buru.

c. Sumber Daya Manusia, dalam hal ini ketidaktegasan pimpinan tertinggi eksekutif dalam memberikan peringatan pada SKPD.

d. TAPD tidak mampu berargumentasi terhadap kegiatan SKPD.

\section{Penyusunan KUA-PPAS}

Prioritas dan Plafon Anggaran Sementara (PPAS) merupakan perumusan kebijakan anggaran yang disusun berdasarkan Kebijakan Umum APBD (KUA), Kebijakan Umum Anggaran (KUA) memuat kondisi ekonomi makro daerah, asumsi-asumsi dasar dalam penyusunan RAPBD dan kebijakan pendapatan, belanja dan pembiayaan daerah serta strategi pencapaiannya. Pada kenyataannya proses penyusunan anggaran dari Musrenbang sudah bermasalah, sehingga tahapan pengajuan KUA-PPAS juga tidak lepas dari masalah, dari hasil penelitian ada dua hal yang terjadi, pertama bahwa pihak Bappeda selaku koordinator penyusunan APBD belum melakukan kajian mengenai kebutuhan anggaran untuk program dan kegiatan SKPD yang bersangkutan, dimana hal ini cenderung menunjukkan bahwa hasil Musrenbang belum menjadi pijakan dalam proses penyusunan anggaran khususnya pada tahap KUA-PPAS. Kedua, pihak TAPD belum memahami urgensi KUA-PPAS. Dari kedua hal ini, dapat diringkas bahwa KUAPPAS belum menggambarkan kebutuhan anggaran pada program dan kegiatan tiap SKPD.

Halim dan Abdullah (2006) Eksekutif membuat rancangan APBD sesuai dengan KUAPPAS, yang kemudian diserahkan kepada legislatif untuk dipelajari dan dibahas bersamasama sebelum ditetapkan sebagai peraturan daerah. Disamping itu Pemerintah Daerah dan DPRD juga harus menjaga dan mengawal adanya konsistensi, sinkronisasi dan sinergitas antara substansi KUA-PPAS, RKA-SKPD/RKA-PPKD RAPBD.

\section{Penyusunan RKA-SKPD}

Dari hasil penelitian ditemukan bahwa RKA-SKPD yang berisi program dan kegiatan sesuai kebutuhan SKPD, namun ketika dibahas bersama DPRD, masih ada evaluasi dari pihak DPRD, dimana hal ini menggambarkan bahwa sinkronisasi program dan kegiatan antara pihak eksekutif dan legislatif melalui kegiatan Musrenbang, maupun kegiatan reses anggota DPRD serta audiens Bupati belum berjalan maksimal. Dengan demikian dapat dirangkum bahwa RKA-SKPD belum mampu menyakinkan pihak DPRD, sehingga dalam pembahasan masih dikoreksi, dimana hal ini memberikan gambaran bahwa RKA-SKPD belum memuat program kegiatan yang sesuai dengan kebutuhan masyarakat.

Harusnya anggaran bisa dimanfaatkan dengan maksimal sesuai kebutuhan, dalam hal ini sebuah kegiatan yang dilakukan oleh pemerintah berpangkal pada skala prioritas dengan itu akan menimbulkan efisiensi dalam pengelolaan anggaran untuk kepentingan publik. sejalan dengan hal diatas, Lukman (1998) dalam Suaib (2015:209) aparat pelayan hendaknya memahami variabel-variabel pelayanan prima seperti yang terdapat dalam agenda perilaku pelayanan prima sektor publik. Variabel yang dimaksud adalah sebagai berikut :

1. Pemerintah yang bertugas melayani;

2. Masyarakat yang dilayani pemerintah;

3. Kebijaksanaan yang dijadikan landasan pelayanan publik;

4. Peralatan atau sarana pelayanan yang canggih;

5. Resources yang tersedia untuk diracik dalam bentuk kegiatan pelayanan;

6. Kualitas pelayanan yang memuaskan masyarakat sesuai dengan standar dan asasasas pelayanan masyarakat;

7. Manajemen dan kepemimpinan serta organisasi pelayanan masyarakat; 
5. Upaya-upaya yang dilakukan Pemerintah Daerah.

Dari hasil penelitian dapat dilihat bahwa perencanaan dan penganggaran APBD di Pemerintah Kabupaten Bolaang Mongondow mestinya sudah harus menerapkan sistem $e$ planning, sehingga perencanaan dan penganggaran APBD mulai dari Bottom Up hingga Top Down dalam hal ini mulai dari tahapan Musrenbang, KUA-PPAS dan RKA-SKPD serta peranan Tim Anggaran Pemerintah Daerah dan Tim Banggar sepenuhnya bertitik pangkal pada skala prioritas anggaran.

Karena dengan menggunakan Teknologi informasi perencanaan (e-Planning) sebagai alat penyusunan RKPD, KUA-PPAS, KUA-PPAS Perubahan, RKPD Perubahan dapat terselesaikan dengan mudah, cepat dan sesuai dengan arahan yang terkandung dalam Permendagri Nomor 54 Tahun 2010. Dengan adanya alat bantu e-Planning Bappeda dapat memaksimalkan sistem juga mampu menyajikan analisisi data yang informatif bagi para pemangku kepentingan. Miarso (2007) teknologi merupakan suatu bentuk proses yang meningkatkan nilai tambah.

\section{PENUTUP}

Berdasarkan analisis terhadap hasil interview, observasi dan studi dokumen yang telah dilakukan oleh peneliti bahwa proses perencanaan dan penganggaran di Pemerintah Kabupaten Bolaang Mongondow adalah sebagai berikut :

1. Proses perencanaan dan penganggaran APBD di Pemerintah Daerah Kabupaten Bolaang Mongondow menggunakan Permendagri Nomor 13 Tahun 2006 dan Permendagri Nomor 59 Tahun 2007 sebagai landasan tapi dalam pelaksanaannya belum sesuai ketentuan. Ketidakpatuhan dalam menerapkan peraturan yang ada maka proses perencanaan dan penganggaran di Pemerintah Kabupaten Bolaang Mongondow terdapat kendala-kendala dalam pelaksanaanya antara lain:

a. Tahapan Musrenbang masih dianggap sebuah proses atau tahapan yang tidak terlalu penting dari perencanaan anggaran.

b. Hasil yang didapatkan dari hasil penjaringan aspirasi masyarakat di tahapan Musrenbang sering tergeser karena adanya kepentingan pihak eksekutif dan legislatif.

c. Transparansi anggaran ditahapan Musrenbang belum sama sekali dilaksanakan ini yang mengakibatkan masyarakat ditahapan Musrenbang banyak mengusulkan rencana dengan harapan ada kegiatan yang nantinya dapat direalisasikan oleh pemerintah.

d. Tersingkirnya hasil Musrenbang karena ketidakpaduan dengan hasil reses anggota DPRD dan reses Bupati dan Wakil Bupati.

2. Kegiatan yang ada dalam KUA-PPAS belum mencerminkan kebutuhan masyarakat yang ada pada tahapan musrenbang. Dikarenakan breakdown RPJMD ke RKPD tidak sinkron disebabkan adanya intervensi pada saat perencanaan juga dikarenakan Bappeda tidak melakukan evaluasi terhadap Rencana Kerja SKPD.

3. Kurang perhatiannya TAPD dan DPRD terhadap jadwal yang ditentukan dalam Peraturan Perundang-undangan.

4. Kurang pahamnya SKPD dalam menyusun kerangka RKPD sehingga menjadikan TAPD hanya menjadi lembaga input kegiatan SKPD saja. Juga dikarenakan ketidakmampuan TAPD dalam memberikan argumentasi kepada tim banggar DPRD menjadikan proses pembahasan perencanaan dan penganggaran menjadi berlarut-larut.

5. Tidak dilibatkannya seluruh stakeholder dalam penyusunan RKA, ini diakibatkan karena pimpinan tertinggi SKPD hanya melibatkan segelintir pegawai sementara perencanaan program dan kegiatan atas nama organisasi.

6. Perencanaan melalui program dan kegiatan yang juga memuat alokasi anggaran disetiap SKPD belum memberikan garansi, karena e-planning baru akan dirancang tahun 2017, sehingga peluang bagi pemotongan alokasi anggaran di program dan kegiatan SKPD masih berpeluang terjadi. 
Berdasarkan hasil penelitian yang telah dilakukan serta kesimpulan yang telah disampaikan dalam penelitian ini, saran yang dapat diberikan bagi Pemerintah Daerah Kabupaten Bolaang Mongondow sebagai berikut:

1. Perlu dilakukan inovasi dalam proses perencanaan dan penganggaran dalam hal ini harus ada sinkronisasi dari tahap awal perencanaan dengan keterlibatan langsung anggota DPRD dalam tahapan awal perencanaan anggaran, sehingga partisipasi masyarakat yang didapatkan dalam tahapan Musrenbang dan reses DPRD serta audiens Bupati dapat disesuaikan sehingga aspirasi masyarakat baik dari Musrenbang, reses DPRD dan audiens Bupati terserap secara maksimal.

2. Pemerintah Kabupaten Bolaang Mongondow harus melibatkan masyarakat bukan hanya dalam tahapan Musrenbang saja namun sampai pada tahapan pembahasan demi terciptanya pemerintahan yang baik (good governance), sehingga kebijakan dari pemerintah tidak membuat antipati terhadap kegiatan yang dilaksanakan.

3. Meningkatkan komunikasi yang positif antara Pemerintah Daerah dan DPRD untuk meminimalisir konflik antara keduanya. Pemerintah daerah perlu mensosialisasikan kembali proses perencanaan dan penganggaran berbasis kinerja yang mengfokuskan pada tujuan dan sasaran yang hendak dicapai.

4. Pemerintah Daerah dalam hal ini TAPD harus melakukan kajian terlebih dahulu pada setiap rencana kerja kegiatan SKPD yang dimasukan agar TAPD mengetahui kegiatan apa saja yang urgen disetiap SKPD, adanya komunikasi yang baik oleh TAPD kepada seluruh Kepala SKPD dalam menyusun anggaran sehingga informasi dan penerapannya tidak hanya terbatas pada Tim Anggaran Pemerintah Daerah saja. TAPD juga perlu memperjelas tugas dan fungsi semua anggota melalui penjabaran tugas kerja masing-masing anggota TAPD.

5. Perlu adanya peningkatan Sumber Daya Manusia sebagai implementor melalui Bimtek dan Diklat khususnya dalam perencanaan dan penganggaran juga harus didukung oleh ASN dan ahli di bidangnya sesuai dengan pendidikan dan keahliannya.

6. Dalam penyusunan RKA-SKPD harus melakukan evaluasi terhadap standar harga, standar belanja, standar pelayanan minimal disetiap program SKPD, juga melakukan evaluasi terhadap kegiatan tahun lalu yang dijadikan rujukan dalam penyusunan RKA tahun depan.

7. DPRD dapat menimimalisir keterlibatan yang sampai pada pembahasan RKA-SKPD serta DPRD harus mengetahui tugas dan fungsi DPRD dalam perencanaan dan penganggaran.

8. Penerapan e-planning bisa memaksimalkan pekerjaan sebab dengan e-planning akan mampu menyajikan analisis yang informatif bagi para pemangku kepentingan dalam hal ini semua stakeholder yang terkait. Dan dengan menggunakan e-planning pekerjaan Bappeda yang berat pun bisa bekerja bekerja efisien karena dengan aplikasi dapat mempersingkat waktu penyusunan rencana, selain itu mudah mengkoordinasikan antara penyusunan rencana pembangunan, pengendalian dan evaluasi pelaksanaannya.

Penelitian ini hanya mencakup proses perencanaan dan penganggaran APBD di Pemerintah

Kabupaten Bolaang Mongondow karena waktu yang cukup singkat dalam penelitian, diharapkan untuk penelitian selanjutnya dapat ditambah dan diperluas dengan menganalisis pelaksanaan dan pertanggungjawaban anggaran, sehingga nantinya hasil dari penelitian analisis penyusunan, pelaksanaan dan pertanggungjawaban, akan ada gambaran yang jelas mengenai pengelolaan keuangan daerah.

\section{DAFTAR PUSTAKA}

Ank Michels \& Laurens De Graaf (2010) “Examining Citizen Participation : Local Participatory Policy Making and Democracy"

Badan Pusat Statistik Bolaang Mongondow. 2014. Bolaang Mongondow dalam Angka. BPS

Bastian, Indra, 2010 "Akuntansi Sektor Publik Suatu Pengantar. Edisi Ketiga. Jakarta. Erlangga.

Bungin, Burhan, 2015 "Penelitian Kualitatif". Jakarta : Kencana Jakarta. Erlangga.

Chandler, R.C. \& J.C. Plano. 1988. The Public Administration Dictionary. Second Edition. Santa Barbara, CA: ABC-CLIO Inc. 
Creswell, John W. 2003. Research Design: Qualitative, Quantitative and Mixed

Approaches. California : Sage Publications, Inc.

Edwards, George C. III. 1980. "Implementing Public Policy". Washington DC: Congresional, Quartely Press.

Halim dan Abdullah 2006, Pengelolaan Keuangan Daerah. Yogyakarta : Sekolah Tinggi Ilmu Manajemen YKPN

Hery. 2013. Teori Akuntansi Suatu Pengantar. Jakarta : Lembaga Ekonomi Universitas Indonesia.

Keban 2014 Administrasi Publik Penerbit Gava Media Yogyakarta (Halaman 59, 68)

Mahsun, dkk 2015, "Akuntansi Sektor Publik". Edisi ketiga.Yogyakarta : PBFE

Mardiasmo. 2004. Otonomi dan Manajemen Keuangan Daerah. Yogyakarta: Andi.

Mardiasmo. 2009. "Akuntansi Sektor Publik". Yogyakarta. CV. Andi Offset.

Maria Yanida, dkk (2013). "Pengaruh Partisipasi Anggaran terhadap Kinerja Aparatur Pemerintah". Universitas Brawijaya, Malang

Matondang. 2015. "Pengaruh Sinkronisasi Perencanaan dan Penganggaran, Partisipasi Anggaran, dan Kejelasan Anggaran Terhadap Kinerja SKPD pada Pemerintah Kabupaten Aceh Utara" Tesis. Syiah Kuala : Pasca sarjana Universitas Syiah Kuala Aceh.

Maya Rostianty, 2010 Analisis Implementasi Belanja Publik dalam Penganggaran Daerah studi kasus Kabupaten Bandung. Tesis, Universitas Indonesia, Jakarta.

Miarso, Yusufhadi. 2007. Menyemai Benih Teknologi Pendidikan. Penerbit Kencana \& UNJ : Jakarta Miles, Mattew B dan A. Michael Huberman, 2009. Analisis Data Kualitatif, Sumber tentang Metodemetode baru. Jakarta : Universitas Indonesia (https://ss.kompas.com)

Modul Pengelolaan Keuangan Daerah edisi 2014, Pendidikan dan Pelatihan Kekayaan Negara dan Perimbangan Keuangan, Jakarta

Musfiqon. 2012. Pengembangan Media dan Sumber Pembelajaran. Jakarta : Prestasi Pustaka

Ni Putu Dewik Erina, 2015. "Pengaruh Partisipasi Penganggaran, Penekanan Anggaran, Kapasitas Individu, dan Kejelasan Sasaran Anggaran pada Senjangan Anggaran Studi empiris pada Kabupaten Gianyar" Tesis : Fakultas Ekonomi dan Bisnis Universitas Udayana, Bali

Nordiawan, Ayuningtyas Hertianti. 2010, "Akuntansi Sektor Publik" Salemba Empat, Jakarta

Peterson, S.A. 2003. "Public Policy". Dalam Encyclopedia of Public Administration and Public Policy.

Diedit oleh Jack Rabin. New York. N.Y. : Marcel Dekker.

Suaib Ridha 2015, Pengantar Kebijakan Publik, Yogyakarta : CALPULIS

RPJMD Kabupaten Bolaang Mongondow 2011-2016, Pemerintah Daerah Kabupaten Bolaang Mongondow

Shakirat Adepeju Babatunde (2013) "The effects of adoption of accrual-based budgeting on transparency and accountability in the Nigerian public sector"

Sjafrizal. 2014, Perencanaan Pembangunan Daerah Dalam Era Otonomi

Smith W. Robert and Mark Bertozzi (1998)."Principals and Agents : An Explanatory model of public budgeting"Journal of Public Budgeting and

Financial Management (Fall) : 325 -353)

Subechan dkk (2014)."Analisis Faktor-Faktor Penyebab Keterlambatan Penetapan APBD Kabupaten Kudus" Brawijaya : Program Magister Ilmu Administrasi Publik Universitas Brawijaya.

Sugiyono. 2015. Metode Penelitian dan Pengembangan, Penerbit : ALFABETA Bandung.

Sugiyono. 2015. Memahami Penelitian Kualitatif, Penerbit : ALFABETA Bandung.

Ventris, C. 2001. "Emerging Perspectives on Participation". Publik Administration Review, May/June.

Watts and Zimmerman, 1986, Positive Accounting Theory, Prentice Hall http://pastiadakomang.blogspot.co.id/2010/04/teori-akuntansi

Yusuf Burhanudin 2015, "Manajemen Sumber Daya Manusia di Lembaga Keuangan Syariah". Jakarta: PT. Raja Grafindo

Zulkifli (2012). Analisis Penyerapan Aspirasi Masyarakat Dalam Anggaran Pendapatan dan Belanja Daerah (APBD) Kabupaten Kutai Kartanegara Tahun Anggaran 2012. Universitas Mulawarman 
Peraturan dan Perundang-Undangan :

Permendagri 21 Tahun 2011 tentang Perubahan Kedua atas Permendagri 13 Tahun 2006 tentang Pedoman Pengelolaan Keuangan Daerah. 2011. Jakarta: Departemen Keuangan Republik Indonesia.

PP Nomor 58 Tahun 2005 tentang Pengelolaan Keuangan Daerah. 2005. Jakarta: Departemen Keuangan Republik Indonesia.

Undang-Undang Nomor 32 Tahun 2004 Tentang Pemerintahan Daerah. 2009. Jakarta : Departemen Keuangan Republik Indonesia.

Undang-undang Nomor 33 Tahun 2004 Tentang Perimbangan Keuangan antara Pemerintah Pusat dan Daerah : Jakarta : Departemen Keuangan Republik Indonesia.

Undang-undang Nomor 17 Tahun 2003 Tentang Keuangan Negara Jakarta : Departemen Keuangan Republik Indonesia.

Undang-undang Nomor 22 Tahun 1999 Tentang Pemerintahan Daerah Jakarta : Departemen Keuangan Republik Indonesia. 